\title{
INOCULACIÓN Y FERTILIZACIÓN FOSFATADA SOBRE EL CONTENIDO PROTEICO DE ALFALFA
}

\author{
Nescier, l. de los M. ${ }^{1}$ \& Dalla Fontana, L. A. ${ }^{2}$
}

\begin{abstract}
RESUMEN
La calidad forrajera de la alfalfa (Medicago sativa L.) en relación a los nutrimentos en el suelo y a la inoculación no son bien conocidas. El objetivo de este trabajo fue estudiar el efecto de la inoculación y la fertilización fosfatada sobre el contenido proteico de plantas de alfalfa. Fueron evaluados los dos primeros cortes de una pastura de la Región Central de la Provincia de Santa Fe, Argentina. El ensayo se realizó sobre un suelo Argiudol típico, con valores de 1,89\% de materia orgánica, 7,2 ppm de P disponible y 995 ppm de $\mathrm{N}$ total, de los 0-20 cm. superficiales. El cultivar de alfalfa elegido fue Cuf $101 \mathrm{y}$ el diseño experimental fue de bloques completos al azar con tres repeticiones. Los tratamientos fueron combinaciones con y sin inoculación y con dos niveles de fósforo. El ANOVA sobre calidad, arrojó que no se encontraron diferencias significativas entre los tratamientos inoculados y no inoculados, ni de los fertilizados con fósforo sobre los contenidos proteicos de las plantas de alfalfa.
\end{abstract}

Palabras clave: alfalfa, inoculación, fertilización, nitrógeno, proteína.

\section{SUMMARY}

\section{Inoculation and $\mathbf{P}$ fertilization on the proteid content in alfalfa.}

Neither nutriments' influence in the soil nor the inoculation with relation to the forage' quality of alfalfa are well-known. The goal of this project was to study the inoculation effect and the $\mathrm{P}$ fertilization over the proteid content of alfalfa plants. The first two cuts of a pasture in the Central Area of the Province of Santa Fe, Argentina, were evaluated. The experiment was done in a tipic Argiudol soil. Values of $1.89 \%$ of organic matter, $7.2 \mathrm{ppm}$ of available $\mathrm{P}$ and $995 \mathrm{ppm}$ of total $\mathrm{N}$ were obtained from the $0-20 \mathrm{~cm}$ top portion of the surface. The chosen alfalfa cultivar was Cuf 101 and the experimental design and the experimental design corresponded to random complete blocks with three repetitions The treatments were combinations with inoculation and without inoculation and with two different levels of P. The ANOVA test of quality indicated that there were not significant differences neither between inoculated and non-inoculated treatments, nor the $\mathrm{P}$ over the alfalfa's proteid contents.

Key words: alfalfa, inoculation, fertilization, nitrogen, protein.

1.- Cátedra de Química. Facultad de Ciencias Agrarias, Universidad Nacional del Litoral. Kreder 2805. (3080) Esperanza, provincia de Santa Fe. Telefax: (03496) 426400. E-mail: inescier@fca.unl.edu.ar

2.- Cátedra de Forrajes. Facultad de Ciencias Agrarias, Universidad Nacional del Litoral. Kreder 2805. (3080) Esperanza, provincia de Santa Fe. Telefax: (03496) 426400. E-mail: ladallaf@fca.unl.edu.ar Manuscrito recibido el 24 de febrero de 2003 y aceptado para su publicación el 17 de mayo de 2004. 